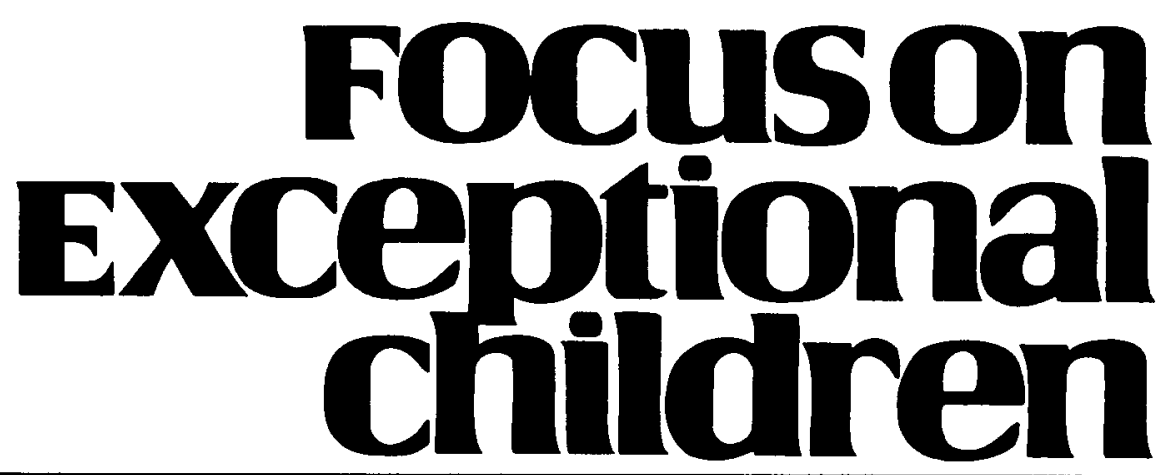

\title{
Gifted and Talented Students at Risk
}

\section{Ken Seeley}

The issue of underachievement among the gifted has captured the interest of educators sporadically over the past thirty years. In the most basic definition, an underachiever is a student who does not achieve in the academic areas at a level consistent with his or her capability. When underachievement is applied to the gifted, it becomes a more complex issue which calls for a new conceptualization.

\section{UNDERACHIEVEMENT AND “AT-RISK" STUDENTS}

Students "at risk" is terminology borrowed from the field of health and wellness and applied to school problems. The question that often arises when the at-risk term is used is, "At risk for what?" The answer may be drug abuse, sexually transmitted disease, school dropout, delinquency, out-of-home placement, or underachievement-to name only a few of the potential dangers. The advantage of casting concerns about gifted problem students in terms of their being at risk, rather than merely underachieving, is that it broadens the net for identification and prevention. Both of these conceptualizations form the basis for this article.

The conceptualization of underachievement in education has gone through many iterations in the last three decades. The whole field of learning disabilities grew from an attempt to explain underachievement as a disabling condition with causes attributed to one or more of the following: brain damage, emotional disorders, early language deprivation, poor acquisition of English for speakers of other languages, economically deprived home situations, poor nutrition, and physical or medical disabilities. Intervention programs have been designed to address these causes, some with more success than others. Clearly, these causes can contribute to underachievement among gifted students. This group is usually referred to as "learning disabled gifted"; they comprise a significant portion of the population of gifted underachievers.

Most gifted underachievers appear to educators as "unmotivated," "lazy," or having behavior problems. Whitmore (1989) urges us to view this population as a result of "underachieving schools" and "underserved groups." This conceptualization helps us to move

Dr. Ken Seeley is president and chief executive officer of the Colorado Foundation for Families and Children. This article is adapted from a chapter he contributed to Counseling the Gifted and Talented edited by Linda Kreger Silverman and published by Love Publishing Company. He has previously been on the faculty at the University of Denver. 
away from blaming the students and their families for underachievement. The blaming mode has been in place for too long and allows educators to avoid responsibility for teaching a group whom they have labeled "capable of doing much better." Given Whitmore's notion, it is the schools that are capable of doing much better because they fail to create appropriate learning environments for children with various learning styles.

Schools are also underserving special populations of gifted students, resulting in underachievement that goes largely unnoticed. When schools do not actively identify giftedness among young children, culturally different students, gifted girls, or special populations, they underserve these students who consequently underachieve in relation to their potential.

A change in conceptualization of underachievement allows us to look at this population as an at-risk group of learners. The semantics are important if we expect schools to take on the task of seeking out and serving underachieving gifted students. The gifted are within at-risk groups that are receiving attention in public education. These groups include dropouts, minority groups, low-income groups, and preschool children. School reform efforts are

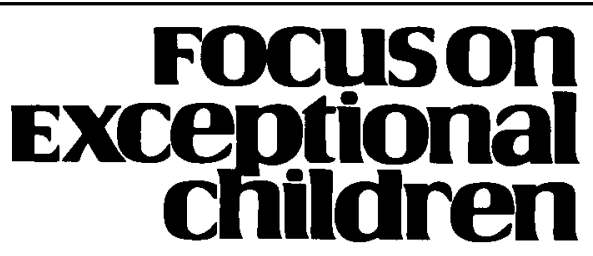

ISSN 0015-511X FOCUS ON EXCEPTIONAL CHILDREN (USPS 203-360) is published monthly except June, July, and August as a service to teachers, special educators, curriculum specialists, administrators, and those concerned with the special education of exceptional children. This publication is annotated and indexed by the ERIC Clearinghouse on Handicapped and Gifted Children for publication in the monthly Current Index to Journals in Education (CIJE) and the quarterly index, Exceptional Children Education Resources (ECER). The full text of Focus on Exceptional Children is also available in the electronic versions of the Education Index. It is also available in microfilm from Xerox University Microfilms, Ann Arbor, MI. Subscription rates: individual, \$36 per year; institutions, $\$ 48$ per year. Copyright $($ ) 2004, Love Publishing Company. All rights reserved. Reproduction in whole or part without written permission is prohibited. Printed in the United States of America. Periodical postage is paid at Denver, Colorado. POSTMASTER: Send address changes to:

Love Publishing Company

Executive and Editorial Office P.O. Box 22353

Denver, Colorado 80222

Telephone (303) 221-7333

Susan T. Warhover Editor
Stanley F. Love Publisher focused on many of these at-risk groups. Even the highly gifted are included in the concerns about math and science achievement.

Inappropriate school environments also put gifted children at risk. In a study of 2,000 middle school students in the upper intellectual quartile, this author found that 37 percent were averaging $\mathrm{C}$ or worse in grade point average (Seeley, 1988). Over half of these students were at risk for dropping out of school due to behavior problems, low grade point average, and poor attendance. Part of the study included a factor analysis to look for causes of the problems that put these students at risk. A reciprocal relationship was found between behavior and grade point average. That is, by lowering students' grades (who are "capable of doing better") the schools inadvertently prompted the students to act out and become behavior problems. Students with behavior problems automatically got lower grades regardless of their ability. This vicious cycle of grading on behavior and behavior producing grades works against high-risk gifted students and results in a push-out program.

Another advantage of considering special populations of gifted students at risk is that preventive steps can be taken before underachievement occurs. By actively looking for giftedness in special populations early in the elementary school years, we can identify this potential and adjust the educational program to the needs of the child.

In summary, it is important to conceptualize the problem of gifted underachievers as students who are at risk for underachievement or school failure. By viewing the problem as students at risk we remove the blaming factors historically assigned to this group and can focus on preventive approaches.

\section{RISK FACTORS}

\section{Disabilities}

The first area to be considered that puts gifted children at risk is disabilities. Those with congenital disabilities such as blindness, deafness, and cerebral palsy are often overlooked and are at risk for not having their giftedness identified because of stereotyped thinking that physical disabilities are associated with mental retardation. Among the deaf and blind, for instance, the incidence of giftedness is the same as in the normal population. Indeed, the population of gifted with physical handicaps has made significant contributions. Maker (1978) interviewed over ninety disabled scientists who not only overcame their disabilities but achieved academic and career success in spite of the educational system that largely treated them as less capable because of their disabilities.

Gifted children with learning disabilities also are overlooked in the typical identification schemes. By definition, 
these children may look slow or "normal" but be capable of much greater achievement than is demonstrated by their performance. Their potential often goes unnoticed by teachers who see them as average or "lazy." Because learning disabilities have a variety of causes and manifestations it is fruitful to look for gifted students in this population through less traditional testing formats. Discrepancies between strengths and weaknesses can be used to determine children with dual exceptionalities. Parents and peers are often reliable in identifying potential giftedness among the learning disabled. Nonacademic interests and products are also good indicators of giftedness.

\section{Low Income and Cultural Diversity}

Poverty is a major risk factor affecting school success because of its effects on family life. Intergenerational poverty contributes to lower parental expectations of children, lower educational level of family members, and poorer general health and nutrition. However, many potentially gifted children come from low-income families and require different approaches to identification and programming than children from upper-income groups.

Because of the greater number of minority groups at the low-income level, minority family status has been mistakenly identified as a risk factor. The underachievement and higher dropout rate for minority group students is a function of poverty, not race or ethnicity. Unfortunately, schools often believe in this false stereotype and create underachievement among minority students through lower expectations.

A survey of "disadvantaged"/gifted programs in the United States was completed by a research team at the College of William and Mary (VanTassel-Baska, Patton, \& Prillaman, 1989). These authors found that the majority of states do not attend to low socioeconomic status as a factor for special consideration in identification, programming, or definitions. Many states (32.7\%) assume that cultural difference accounts for low-income groups. They also report that a majority of the states $(78.8 \%)$ do not differentiate programs or services for disadvantaged gifted, nor do they use special assessment techniques to identify this special needs group. One recommendation from this survey was to drop the term disadvantaged to describe culturally diverse or low-income groups because of the negative connotation. It will take a concerted effort to dispel the stereotype that cultural difference implies low income and poor achievement. A demand for appropriate identification and programming will help raise consciousness of these issues and, hopefully, will result in better service to this population of at-risk gifted youth.

\section{Delinquency}

There has been much speculation about the relationship of giftedness and juvenile delinquency, with two opposing theories at work. One notion is that gifted youth are more vulnerable to delinquency because of their heightened sensibilities and intellectual characteristics, which make them feel different from other children. They often do not feel they fit in well in their environment. Thus, the gifted are more likely to be adversely affected by problems at home or school. The opposing theory is that giftedness is a protection against proneness to delinquency. Because of higher ability, youths have a greater insight into their own actions and those of others, and can see the long-range consequences of their behavior. As a result, they are more able to understand and cope with environmental conditions and are not as likely to be at risk for delinquency. The protection theory suggests that environmental conditions must become extremely unfavorable to cause a gifted child to become delinquent (Mahoney, 1980).

A careful review of the research reveals that both theories are true depending upon the cognitive style of the gifted child (Seeley, 1984). If the young person's abilities are largely creative and divergent, she or he is probably more vulnerable to delinquency. In contrast, a convergent thinking style with strong achievement motivation usually provides protection from risk of delinquency. The home and school environments, of course, are major influences for either type of cognitive style and affect the degree of risk.

In a study of 300 youths in a juvenile justice system, an interdisciplinary team from the University of Denver found a disproportionately larger number of gifted subjects than would be expected (Mahoney \& Seeley, 1982). Most of these youths were the vulnerable types discussed previously, who demonstrated high levels of fluid ability rather than crystallized abilities. Horn (1978) describes fluid ability as an intelligence that is not taught but is characterized by a quick perceptiveness and intuitive ability used to process information and solve problems. Conversely, crystallized ability is a type of intelligence that takes in and uses information from the environment to solve problems and understand phenomena. Convergent thinkers are high in crystallized abilities and are usually achievers because they meet teacher expectations. Gifted students with high levels of fluid ability seem to be at greater risk for delinquency and poor school performance. As with other types of gifted students at risk, they have abilities that may not be identified with existing procedures or addressed in the classroom. In determining levels of risk it is important to differentiate the cognitive style of the individual and to further specify the types of abilities shown.

\section{School Environment}

School does seem to play a role in promoting underachievement in certain types of students whom educators view as less desirable; this is clearly suggested by the 
middle school study of dropouts reported earlier (Seeley, 1988). The self-fulfilling prophecy moves forward from this point. Giftedness compounds this dynamic, particularly for those fluid ability students who are smart but not achieving. Add to these factors contentious relationships at the onset of adolescence and we have the perfect formula for frustration, alienation, school failure, and school dropout.

In a companion study, 128 gifted high school dropouts were interviewed to determine some of the factors that these former students attributed to their choice to leave school (Seeley, 1988). The following list is a summary of school environment risk factors that emerged from the study:

- Attendance rules tended to push out students.

- Academic work was seen as too easy, boring, and repetitive.

- School size was reported as too big, impersonal.

- School-supported cliques were alienating (e.g., athletes, honor students).

- Uneven academic performance led to the school focusing on weaknesses.

- School starting time was seen as too early.

- There was lack of flexibility in daily school schedule.

- Frequency of school changes was a major factor.

- Conflicts with teachers began at junior high school (not in elementary grades).

- Teacher/counselor attitude was "shape up or ship out."

- Teacher indifference or hostility was a major factor.

- Teachers who did not like what they were teaching was an obvious problem.

- Students wanted respect and responsibility.

- Assignments were often seen as busywork.

- There was too little experiential learning.

It is interesting that almost all of the dropouts assumed full responsibility for their decision. They did not externalize or blame the school, but rather indicated their choice to leave was an adaptive response to a poor situation that did not fit for them. Most indicated that they would go back to a different educational program and continue their education at a community college or an alternative school if that were available. This is important to keep in mind when solutions are discussed later.

\section{ADOLESCENCE}

Normal developmental periods can put young people at risk if the home or school does not adapt to developmental changes in their behavior. This is amplified for gifted children who often appear to be more mature than they really are. Because of advanced verbal reasoning, they are expected to act older than their chronological age. Many parents or teachers wonder why a young person so smart can do such dumb things sometimes. But adolescence is marked with inconsistencies between thought and action.

Gifted adolescents often labor under an externally imposed set of goals-aspirations that are not theirs, but rather their parents' or teachers'. During the middle school years many gifted youth begin to challenge these external standards. It is precarious to have an adult thinker in the body of an adolescent and be expected to act "gifted" in order to meet the requirements of others for high performance. The imposition of external standards combined with the normal adolescent needs for separation and search for identity may result in stress and alienation expressed in underachievement, antisocial behavior, or indifference. Educators and parents must allow adolescents to take time to explore options, develop their own vision, and understand their own developmental stages. Adults also need to encourage input from young persons about decisions affecting their lives. This promotes independence and acknowledges the adult mind of the gifted adolescent. Gifted youth should be taught the stages of normal development so they can gain insights and develop healthy responses to thoughts and feelings they might otherwise regard as strange or disturbing.

\section{MOTIVATION}

Recent research and theoretical development on the various facets of motivation were reviewed by Nicholls and Miller (1984) and Ackerman, Sternberg, and Glaser (1989). This literature sheds light on the relationships between levels of ability and underachievement. One major influence in underachievement is the level of motivation of the student. This multifaceted concept is usually discussed in education circles as a unitary quality over which the student is expected to exercise control. When motivation is perceived as an inherent characteristic of the student, underachievement is explained simplistically as "lack of motivation," and the subtle message is to blame the student. This distorted cause-and-effect relationship may help educators feel better but does little to solve the problem for the student.

In discussing adolescents and motivation, Csikszentmihalyi and Larsen (1984) state,

\footnotetext{
Both negative feelings and passivity relate to a ... process that can block the efficient use of attention: loss of motivation. When something stands in the way of a person's goals, when goals become confused, or when external goals are imposed by adults, adolescents become disinterested and have a hard time investing psychic energy in their pursuits. This is a state in which thoughts and actions are in conflict. (p. 21)
}

Apparent lack of motivation springs from inner conflict involving the student's goals, which affects interest level. 
The dynamic expressed so well by these authors helps define the basics of motivation and attribution. At a minimum, this definition provides the broad parameters for analysis of the relationship between underachievement and motivational factors. When we see underachievement and think motivational problem, we need to ask the following questions as educators:

- What are my goals and expectations for this student?

- What are the student's goals and expectations relative to this learning task?

- Are the goals unclear for either me or the student?

- Are the goals in conflict?

- What are the barriers to our respective and collective goals?

- What is the student's interest level in this learning task?

- If goals are different, how can I bring them into concert?

- If the interest level is not high, how can I increase it? (Csikszentmihalyi \& Larsen, 1984)

The answers to these questions provide both an assessment of the problem and the teaching strategy. We avoid labeling the student as unmotivated by engaging the student in a thoughtful discussion about goals, interests, and barriers.

In examining motivation and learning strategies, Ames and Archer (1988) studied academically advanced students as to their goal orientation and perceptions of classroom experiences. Goal orientations were described as either performance goals or mastery goals. Performance goals relate to being judged able; students believe that successful performance defines their level of ability. Mastery goals, on the other hand, focus on developing new skills and indicate that the learning process and effort are valued. Findings revealed that when students perceived mastery goals they preferred tasks that were challenging and used more effective learning strategies (Dweck, 1986). In other words, they appeared to be more highly motivated in an environment that valued learning over pure performance. This is particularly important in an age when outcome-based education is in vogue. It would be easy for educators to create a performance goal environment where success is the performance, not learning or effort. Further, Ames and Archer (1988) suggest that

[a] mastery, but not a performance structure provides a context that is likely to foster long-term use of learning strategies and a belief that success is related to one's effort ... modifying the goal structure of a classroom in such a way that mastery goals are salient and are adopted by students may also be necessary to elicit adaptive motivation patterns. (p. 265)
The linkages between goals, learning, and motivation are clear and form the basis for understanding the causes of underachievement. Self-esteem of the learner is also affected by this interaction of goals, learning strategies, and motivation and as such is at the root of the solution.

\section{TOWARD SOLUTIONS}

As indicated at the beginning of the article, we have moved away from blaming at-risk children and their families for lack of achievement. This is not to say that schools are unilaterally responsible for solutions. Parents and gifted children need to be heavily involved in the educational decision-making process in order to invest in the solution.

Special approaches are needed for gifted underachievers whose alienation becomes overwhelming. They need to overcome both the fear of success and the fear of failure that entrap them. When these feelings of alienation become great enough, they contribute to putting students at risk when the students try to reconcile their identity crises in maladaptive ways. It is incumbent upon us as educators and counselors to provide appropriate support to these students. Special tutoring and peer counseling programs can be effective solutions.

In order to address the feelings of alienation and isolation among at-risk students, a sense of community needs to be developed at school. Many students in the mainstream of school life experience this feeling of community, of belonging, of counting in someone else's life. At-risk students, on the other hand, are outside of the community and feel like aliens in a strange and distant place. Alternatives are needed that foster community to different groups of students. One important option is community service. Like other students, at-risk students want to find a caring environment at school, but also they need to be caring and giving about something important to them. School-sponsored community service options can be an excellent way to involve these students who might not choose pep club, football, or chorus as a vehicle for feeling a part of the school community.

The final part of this article is an outline of activities suggested by students and educational leaders who were assembled at a workshop designed to develop solutions to the problems of underachievement and school dropout (Seeley, 1988). Five areas were identified as targets of intervention: peer/social relationships, home and family, minority status of students, teacher issues, and school environment issues. This part is presented as a blueprint for local counselors or educators to use as a framework for discussion and planning at the school level. Each solution presents an objective and a set of strategies. This is merely a beginning for local initiatives to address the complex problems of underachievement. 


\section{PEER AND SOCIAL RELATIONSHIPS}

OBJECTIVE 1.1: Provide more flexibility in schools to foster peer and social relationships among students.

EXPLANATION: The major reason most students come to school is for the social interaction with other students. Instead of trying to deny the social learning of interpersonal relationships, educators should maximize this motivational factor and structure learning in teams, groups, dyads, peer tutorials, etc.

\section{STRATEGIES:}

- Allow students to do more teaching of others.

- Organize K-8 schools for the gifted.

- Promote student planning of space utilization.

- Organize multi-age groups across grade levels.

OBJECTIVE 1.2: Assist students with successful transitions.

EXPLANATION: What we know of human development for all ages is that transitions are difficult emotionally, logistically, intellectually, and developmentally. We also know that transitions are important growth experiences out of which come rich and enduring life skills. We can do much to capitalize on these periods in schooling.

\section{STRATEGIES:}

- Develop adoption program of younger students by older students.

- Offer transition "survival courses" when changing grade levels/schools.

- Arrange summer jobs for students based at schools.

- Offer longer-term orientation programs at transition points.

- Provide parent education programs about transitions.

- Allow parent-student input for selection of teachers for next level.

OBJECTIVE 1.3: Provide an effective counseling/advisement program.

EXPLANATION: School counseling has never been a strength of public education. This is largely because the counselors are usually expected to do too much with too many students. Advisement expands the reach of counselors and meets important goals for guiding students and building advocates for them.

\section{STRATEGIES:}

- Use all school personnel as advisors after training them.
- Provide elementary counselors for preventive services.

- Develop peer counseling programs.

- Promote small-group meetings for problem solving.

- Provide small-group topical meetings (e.g., divorce, transitions, etc.).

- Develop family-school support systems with meaningful family involvement.

- Provide screened referrals for students and families with special needs.

OBJECTIVE 1.4: Promote empowerment and autonomy for students.

EXPLANATION: Students need greater control over their own learning if they are to be responsible for and invested in their education. Teachers who share power and control usually earn the respect of their students and find more motivated learners in their classes.

\section{STRATEGIES:}

- Solicit student input for teacher planning of learning activities.

- Implement a self-paced/mastery learning curriculum.

- Solicit student input into school policies and personnel hiring.

- Promote recognition and awards for achievement and effort.

- Provide leadership training and school outlets for leadership.

- Involve students in evaluating the school and solutions for improvement.

- Develop community service/school service opportunities.

\section{MINORITY STUDENT INVOLVEMENT}

OBJECTIVE 2.1: Promote cultural competence in all students.

EXPLANATION: The concept of cultural competence implies a set of generic skills that can be applied to developing sensitivity to ethnic, racial, or language differences in people. This sensitivity and awareness does not promote stereotypic characteristics of cultural groups, but rather aims to value difference with an openness and comfort to explore the meaning of the cultures between and among those involved.

\section{STRATEGIES:}

- Celebrate the rich cultural heritage and language diversity of students. 
- Develop programs that aim to be competent in their understanding of the cultural context in which students and their families live, work, and learn.

- Provide staff development to gain knowledge and respect for cultural differences among the students and their families and the staff.

OBJECTIVE 2.2: Develop gifted programs that are sensitive to diversity.

EXPLANATION: Historically, gifted programs have been associated with an overrepresentation of white students. Identification procedures and program design and content should invite cultural diversity while maintaining high standards and fast pace.

\section{STRATEGIES:}

- Involve minority staff and students in the identification process.

- Actively recruit minority teachers/mentors for gifted programs.

- Define giftedness in the cultural context of each minority group in the community.

- Use community-based organizations as change agents in school reform and to assist in educational staff development.

\section{APPROPRIATE TEACHER/COUNSELOR ROLES}

OBJECTIVE 3.1: Improve communication between teachers and counselors as to underachievers.

EXPLANATION: Team planning between teachers and counselors for underachieving students is essential in addressing their needs. Communication needs to be valued, scheduled regularly, and follow an agreedupon protocol that is efficient.

\section{STRATEGIES:}

- Create a teacher-advisement program with counselor supervision.

- Use the advisement program to find underachievers and develop a plan.

- Give release time to effective advisors to work with underachievers.

- Develop IEP approaches and monitor carefully.

- Allow counselors sufficient time to support teacher-advisors through training, group problem solving, identification of resources, and referrals as needed.

OBJECTIVE 3.2: Incorporate self-esteem development as a legitimate curriculum concern for teachers and their students.
EXPLANATION: Much lip service is paid to the importance of developing good self-esteem as a precursor to learning, but it is still regarded by many educators as a frill or "touchy-feely nonsense." Teacher time and self-esteem curriculum need to be endorsed by administrators and curriculum leaders as important and expected as routine classroom activities along with the traditional curriculum topics.

STRATEGIES:

- Use a homeroom system with small group meetings and periodic debriefings with students.

- Develop and monitor a community mentorship program.

- Use goal-setting and decision-making activities with students in planning for learning.

OBJECTIVE 3.3: Improve the learning environment for students.

EXPLANATION: Generally, school reform efforts suggest creating an "inviting" learning environment for all students. This is essential for underachievers who need an extra measure of teacher caring and attention to their individual strengths and needs.

STRATEGIES:

- Expand learning beyond the classroom into the community.

- Allow students to participate in governance.

- Use flexible instructional groups based on needs.

- Promote year-round learning opportunities.

- Support the development of alternative schools at all levels.

- Promote pass/fail/incomplete system of grading.

- Encourage positive confrontation and conflict resolution.

\section{CONCLUSION}

Giftedness and underachievement is a complex, multiproblem phenomenon which has been grossly oversimplified in cause, concept, and approach. This article has moved from a simple base definition through a network of risk factors, potential causes, and approaches that make learning more accessible and possible for large numbers of at-risk students. The restructuring of education may result in many of the reforms mentioned in the blueprint above. However, individual professional caring and persistence must be applied with structural change. Understanding the role of motivation and planning realistic goals with students can build on strengths and interests and move the gifted underachiever out of risk. Surely we cannot afford to lose this 
important potential talent. Counselors and teachers can make an important difference to avoid this loss for student, school, and society.

\section{REFERENCES}

Ackerman, P. L., Sternberg, R. J., \& Glaser, R. (1989). Learning and individual differences. New York: W. H. Freeman.

Ames, C., \& Archer, J. (1988). Achievement goals in the classroom: Students' learning strategies and motivation processes. Journal of Educational Psychology, 80, 260-267.

Csikszentmihalyi, M., \& Larsen, R. (1984). Being adolescent: Conflict and growth in the teenage years. New York: Basic Books.

Dweck, C. S. (1986). Motivational processes affecting learning. American Psychologist, 4l, 1040-1048.

Horn, J. (1978). The nature and development of intellectual abilities. In R. T. Osborne, L. E. Noble, \& N. Weyl (Eds.), Human variation (pp. 107-136). New York: Academic Press.

Mahoney, A. R. (1980). Gifted delinquents. Children and Youth Services Review, 2, 315-330.
Mahoney, A. R., \& Seeley, K. R. (1982). A study of juveniles in a suburban court. Technical report. Washington, DC: U. S. Dept. of Justice, OJDPP.

Maker, J. (1978). Handicapped gifted scientists. A special report to the Council for Exceptional Children. Reston, VA: CEC.

Nicholls, J. G., \& Miller, A. T. (1984). Development and its discontents: The differentiation of the concept of ability. In J. G. Nicholls \& M. L. Maeher (Eds.), Advances in Motivation and Achievement (Vol. 3, pp. 185-218). Greenwich, CT: JAI Press.

Seeley, K. R. (1984). Giftedness and juvenile delinquency in perspective. Journal for the Education of the Gifted, 8, 59-72.

Seeley, K. R. (1988). High ability students at risk. Technical report. Denver: Colorado Department of Education.

VanTassel-Baska, J., Patton, J., \& Prillaman, D. (1989). The disadvantaged gifted: At-risk for educational attention. Focus on Exceptional Children, 22(3), 1-15.

Whitmore, J. R. (1989). Re-examining the concept of underachievement. Understanding Our Gifted, 2(1), 1, 7-9.

\section{PERMISSIONS AND COPYRIGHT}

All rights are reserved. No part of this publication may be reproduced, photocopied, faxed, stored in a retrieval system, or transmitted in any form or by any means, electronic, mechanical, recording or otherwise, without the prior written permission of the publisher.
Back issues are available for sale. Reproduction requires permission and payment of fees. It is illegal and a violation of federal copyright law to reproduce this publication without permission. Direct all inquiries to the permissions editor. 
Copyright of Focus on Exceptional Children is the property of Love Publishing $\mathrm{Co}$. and its content may not be copied or emailed to multiple sites or posted to a listserv without the copyright holder's express written permission. However, users may print, download, or email articles for individual use. 